\title{
架橋型熱可塑性エラストマー（TPV）の構造と 力学物性に関する研究
}

\section{1. 緒言}

ポリオレフィン系材料, 中でも，ポリプロピレン (PP) は, 加工性, 耐薬品性, 強度, 伸び, 加工性に優れている ため, 世界で最も広く使用されている半結晶性高分子材料 の一つであるが，脆性的な高分子材料であるため，降伏勒 性, 耐衝撃性に劣っている。一方, 軟質系高分子材料とし ては，軟質塩化ビニル樹脂（軟質 PVC），加硫ゴムなどが 使用されているが, 環境保護, 成形性, リサイクル性など の観点から, 熱可塑性を示すポリオレフィン系の軟質高分 子材料が注目されている。脆性的なポリプロピレンを柔軟 化するために，共重合や異種ポリマーとのブレンドなどの 方法が行われているが, 簡易で, 効果的なゴム（エラスト マー）とのブレンドによる改質が広く行われている。この ような中で, ポリオレフィン系の架橋型熱可塑性エラスト マー (TPV) はPP とポリオレフィン系ゴム (エラストマー) とのブレンド材料であり, 1970 年代後半に製品化されて 以来 ${ }^{1)}$, 環境負荷の低い材料として, 自動車, 建築材料な どに積極的に使用されている ${ }^{2) \sim 6)}$ TPV は非相溶系の高分 子ブレンドの一つであり, PP と架橋前ゴムを混練させな がらゴム部を架橋させる動的架橋などにより作製され，ゴ 厶的弾性と熱可塑性の両方の特性を有する非常に特徵的な 高分子材料である. TPV は脆性的な熱可塑性樹脂を海相, 組成比率が高い架橋ゴムを島相とする海島構造を呈する. 海相が脆性を示す堅い樹脂であるにも関わらず，TPVは ゴム的弾性や高い延伸性を示す。ゴム的弾性, 高延伸性を 有する TPVは，環境保護，成形性，リサイクル性の観点 から軟質 PVC, 加硫ゴムの代替材料として大変注目され ている．しかし完全に代替するためには，より高いゴム弾 性, 延伸性を有する TPV の開発が必要となる。高いゴム 弾性と延伸性を有する TPVを開発するためには, TPV のゴム的弾性・延伸性の発現機構を明確にすることが不可 欠になり, 種々の研究が行われてきたが, この発現機構に

\footnotetext{
*1 Asami, Takuo

三井化学(侏) 機能樹脂研究所

市原市千種海岸 3 ( ( 299-0108)

${ }^{* 2}$ Nitta, Koh-hei

金沢大学大学院 自然科学研究科

2005.12.26 受理
}

浅 見环 夫*1 新 田晃 平*2

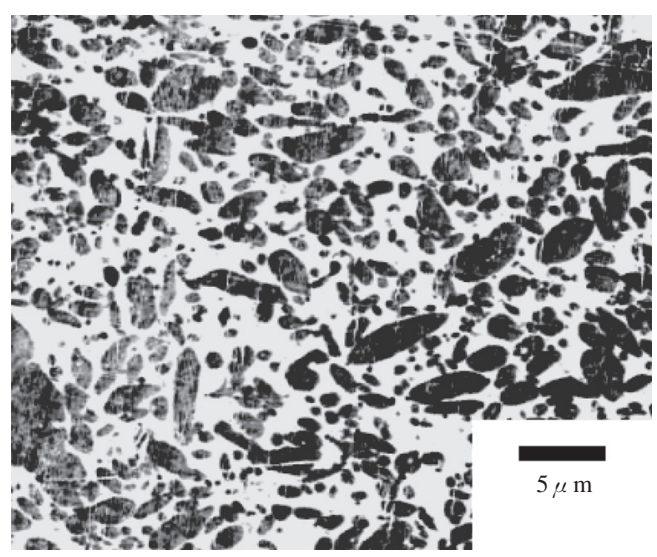

図 1 TPV-PP 40 の TEM 観察像.

白色相 iPP, 黒色相 架橋ゴム

ついては十分に明確化されていなかった ${ }^{7) \sim 13)}$.

本研究では, 海島構造を有する TPVのモルフォロジー と力学物性の関係について検討を行った. TPVのゴム的 弾性, 延伸性の発現機構について, 分子論的, 構造論的解 釈を与え，より高いゴム的弾性と延伸性を有する TPVの 開発指針を与えることを目的とする。

\section{2. 実験}

\section{1 試料}

本研究では, 最も代表的なイソタクチック PP (iPP) と エチレン・プロピレン・ジエン・モノマー（EPDM）系の TPV について検討した. TPV 試料は iPP の混合比率を 20 〜80 wt\%にし，iPP と EPDM を混練しながら動的架橋を 行うことにより作製した。試料名は，iPP の混合比率を用 いて，TPV-PP 20〜TPV-PP 80 とし，iPPの混合比率は $40 \mathrm{wt} \%$ である TPV-PP 40 がもっとも代表的な TPV 試料 になる.図 1 に TPV-PP 40 の透過型電子顕微鏡 (TEM) による観察結果を示したが，白い iPP 海相中に，黒く染色 された EPDM 相が, 島相として $\mu \mathrm{m}$ オーダーで微分散し ている.

\section{2 測定}

フィルムをノッチ型に打ち抜いた試料を用いて，引張試 験機により応力ーひずみ曲線を測定した.

引張試験機によりひずみ 5.5 まで延伸した試料を治具か 


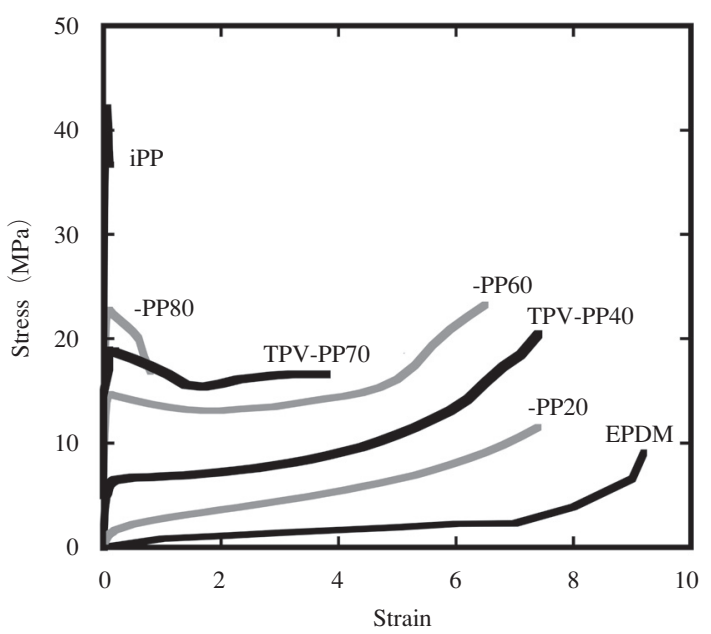

図 $2 \quad \mathrm{TPV}, \mathrm{iPP}$, 架橋 EPDM の応力ひずみ曲線

ら取り出し, ルテニウム酸で染色した後, 走査型電子顕微 鏡 $(\mathrm{SEM})$, 透過型電子顕微鏡 $(\mathrm{TEM})$ を用いて変形後 のモルフォロジー観察を行った.

引張 $\rightarrow$ 圧縮変形下の分子配向の解析は FT-IR の二色比 を用いて行った. フィルム試料を両軸引張型の専用治具に 固定し, 延伸・圧縮しながら, iPP 非晶として $974 \mathrm{~cm}^{-1}$, iPP 結晶として $841 \mathrm{~cm}^{-1}, \mathrm{EPDM}$ として $722 \mathrm{~cm}^{-1}$ の吸収 バンドを使用し，これらの二色比より配向関数を算出し， 解析した ${ }^{14) \sim 16}$.

応力ーひずみ曲線に対する iPP 結晶性の影響を解析する ために，スペーサーを用いずに溶融熱プレスを行った後，

(1)水冷, (2)水冷した試料を $100^{\circ} \mathrm{C}$ で熱処理, (3) $100^{\circ} \mathrm{C}$ で固 化の 3 種類の試料を作製し, 両軸引張型試験機で応力ひず み曲線を測定した。

溶融プレス後, 所定の温度で長時間アニーリングするこ とにより孤立球晶を作製し，この試料を専用治具により手 動で延伸しながら，偏光顕微鏡を用いて変形下の球晶観察 を行った。

\section{3 . 結果と考察}

\section{1 応力ーひずみ曲線}

図 2 に各種 TPV と iPP, 架橋 EPDM の応力ひずみ曲線 を示す．島相として分散している架橋ゴムが $30 \mathrm{wt} \%$ を超 えると（TPV-PP 70），主成分である iPP 海相が脆性的な 性質を示すにも関わらず，高い延伸性を示した。

\section{2 変形後のモルフォロジー}

TPV-PP 40 について，ひずみ 5.5 まで延伸した試料の SEM 観察結果を図 3 に示す。iPP 海相中に分散した架橋 ゴムよりなる島相が延伸方向に引き伸ばされていることが わかった。

さらに詳細に解析するために，iPP の微細構造に着目し， TEMによる高倍率の観察を行った。図 4 に示したように, 引き伸ばされた島相の赤道面付近の iPP 海相に引っ張り方 向と垂直にクレーズが発生していることが観察された。ま た，このクレーズ付近では，iPPのラメラ構造は観察され なかった。一方, 延伸された島相の極地付近の観察結果を 図 5 に示す。この領域では, クレーズは見られず，iPPの

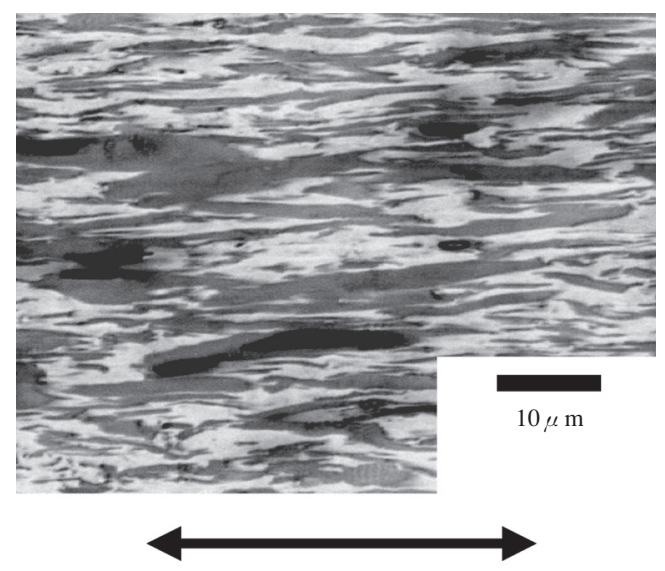

図 $3 \gamma=5.5$ まで延伸した TPV-PP 40 の SEM 観察像. 矢印が延伸方向

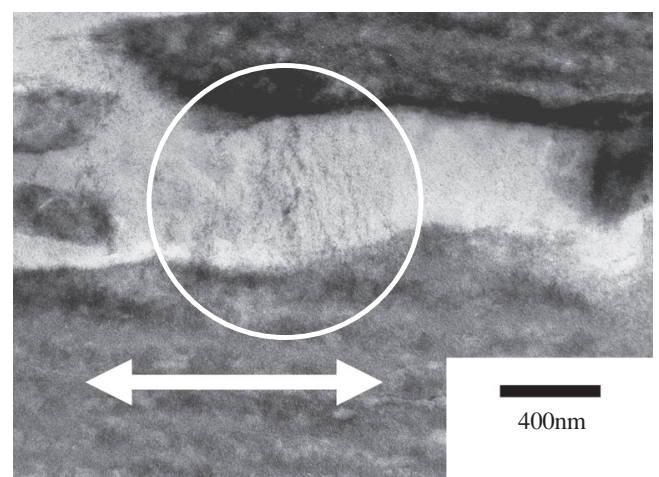

図 $4 \gamma=5.5$ まで延伸した TPV-PP 40 の TEM 観察像. 矢印が延伸方向。

延伸された島相の赤道面付近の iPP 海相. 丸印内が クレーズ

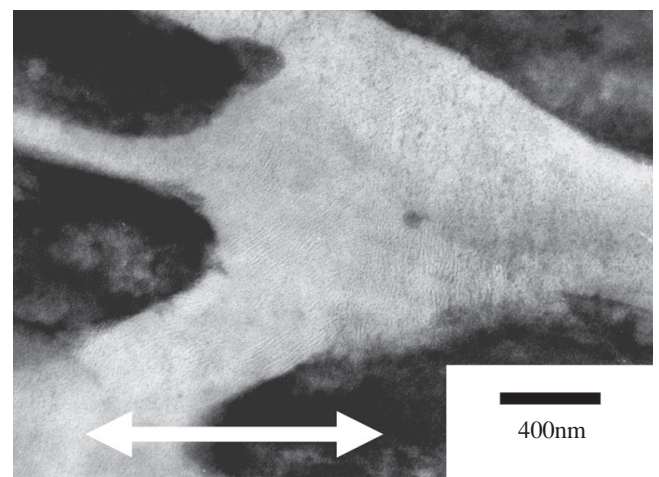

図 $5 \gamma=5.5$ まで延伸した TPV-PP 40 の TEM 観察像. 矢印が延伸方向.

延伸された島相の極地付近の iPP 海相

ラメラ構造も明瞭に観察された。延伸過程の有限要素法解 析（FEM）により，変形初期では，引き伸ばされた島相 の赤道面付近の $\mathrm{iPP}$ 海相にひずみの集中が起こることがシ ミュレーションで明らかになっている ${ }^{17)}$ FEM の解析結 果と, 電子顕微鏡の観察結果より, 変形初期では, 引き伸 ばされた島相の赤道面付近の $\mathrm{iPP}$ 海相にひずみが集中し, iPP が破砕すること，この結果，架橋ゴム島相は iPP 海相 


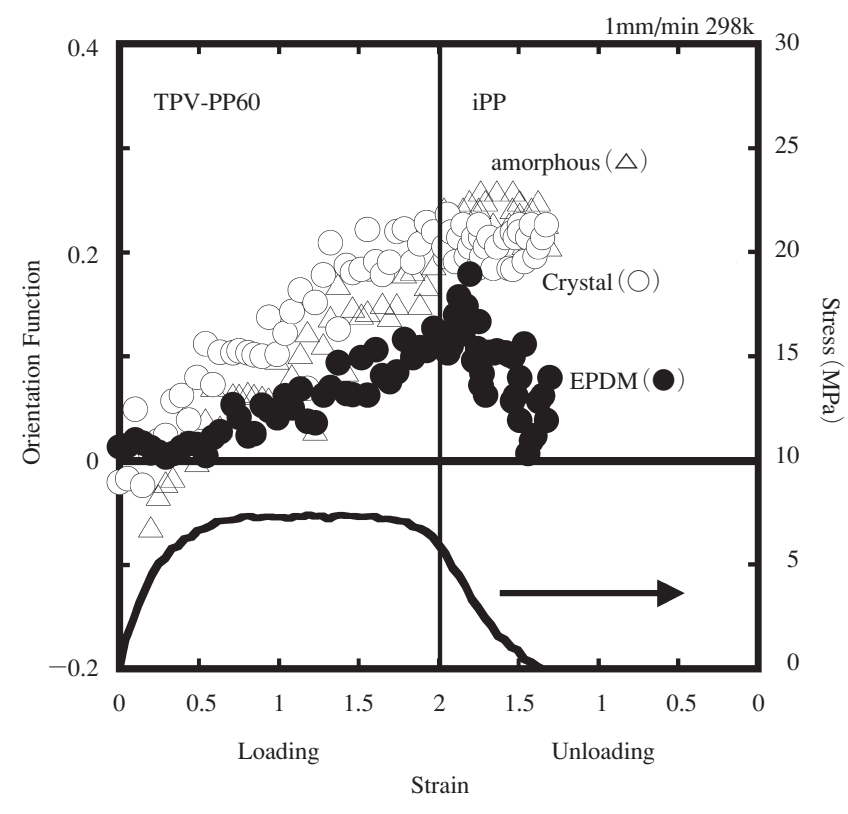

図 62 倍延伸後, ひずみを戻した時の TPV-PP 60 の iPP 非晶 $(\triangle)$ ，iPP 結 晶 $(\bigcirc), \operatorname{EPDM}(O)$ の IR の 配向関数と応力ひずみ曲線

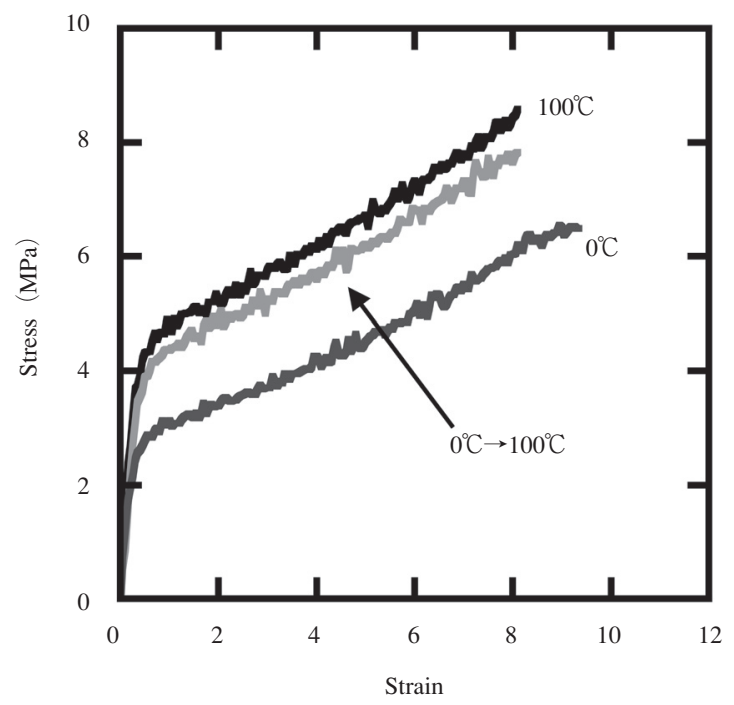

図 7 溶融時からの熱処理方法が異なる TPV-PP 40 の応 力ひずみ曲線

による拘束から解放され, 変形しない極地付近の iPP 相を 通して，架橋ゴム島相が変形することにより，TPVが延 伸性を発現することが明らかになった。

\section{3 変形下の分子配向}

ひずみ 2 まで延伸した後，ひずみを 0 に戻したときの， $\mathrm{TPV}$ 中の $\mathrm{iPP}, \mathrm{EPDM}$ の IR の配向関数を図 6 に示す. EPDM の配向は 0 まで戻り, 弾性的な挙動を示すが, iPP の配向は戻らず，塑性的な挙動を示すことがわかった。こ の結果から, 海相である iPP は TPVのゴム弾性の発現に 寄与せず，架橋 EPDM 島相のみが，ゴム弾性発現に寄与 していることが明らかになった。

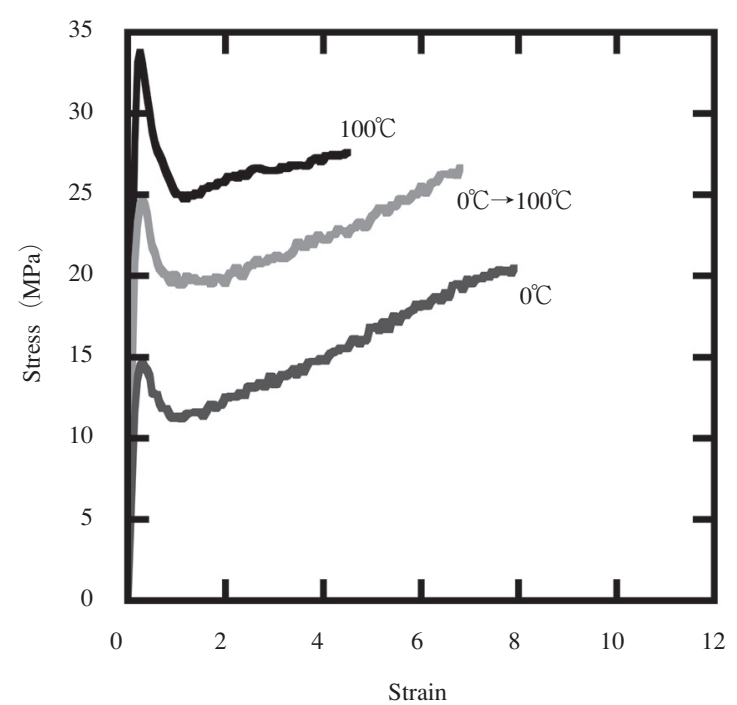

図 8 溶融時からの熱処理方法が異なる iPP の応力ひずみ 曲線

\section{$3.4 \mathrm{iPP}$ 結晶性の異なる応力ひずみ曲線}

$\mathrm{iPP}$ の結晶性の異なる TPVの応力一ひずみ曲線を図 7 に示す。iPP 中の結晶化度が $30 \%$ と低い(1) $0{ }^{\circ} \mathrm{C}$ で水冷した $\mathrm{TPV}$ のみ応力レベルが低い. 一方，(2)水冷した後 $100^{\circ} \mathrm{C}$ で熱処理した試料と (3) $100^{\circ} \mathrm{C}$ で固化させた試料では iPP 中 の結晶化度はともに $65 \%$ と同程度であり，応力レベルに 差は無かった。これらより，架橋によりゴム島相の構造が 安定化され, 熱処理などにより構造変化を起こさないので, $\mathrm{TPV}$ の応力レベルは iPP 結晶化度の差にのみ起因してい ることがわかった。

$\mathrm{iPP}$ 単体の結果を図 8 に示したが，TPV と同様，結晶 化度の低い(1) $0{ }^{\circ} \mathrm{C}$ 氷冷した $\mathrm{iPP}$ の応カレベルが低かった。

一方, $\mathrm{TPV}$ とは異なり, (20 $0^{\circ} \mathrm{C}$ で水冷後 $100^{\circ} \mathrm{C}$ 熱処理し た試料と (3) $100^{\circ} \mathrm{C}$ で熱処理した試料を比較すると, iPP 単 体では応力レベルが異なった．熱処理方法の違いにより， 結晶化度は同程度であるが，iPP の球晶のような数十 $\mu \mathrm{m}$ レベルの大きいサイズの構造に差が生じる。これらの結果 より, iPP 単体では, サイズの大きい球晶構造が応力レべ ルに影響を及ぼすが，TPVの応力レベルは，球晶のよう な大きな構造には依存せず，iPP の結晶化度のみに関係す ることが示唆された。

\section{5 変形下の球晶観察}

この要因を明確にするため, 変形過程下の球晶の観察を 行った. iPP 単体の球晶は不均一にクラックが発生するが18), 図 9 に示したように，TPV中の iPP 球晶では，均一にク ラックが発生した。図 4 の TEM 観察像より, 球晶の大き

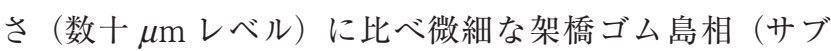
〜数 $\mu \mathrm{m}$ レベル)で，クレーズが発生する. そのため, TPV では球晶のような大きな構造に関係なく，架橋ゴム島相を 起点としてクレーズ，クラックが発生することが明らかに なった。これらの結果より, TPVの延伸過程下では, 引 き伸ばされた架橋ゴム島相の赤道面付近の iPP 海相で破砕 したiPP の微細結晶が, 架橋ゴム島相からの変形を受け, TPV の応力発現に寄与することが明らかになった。 


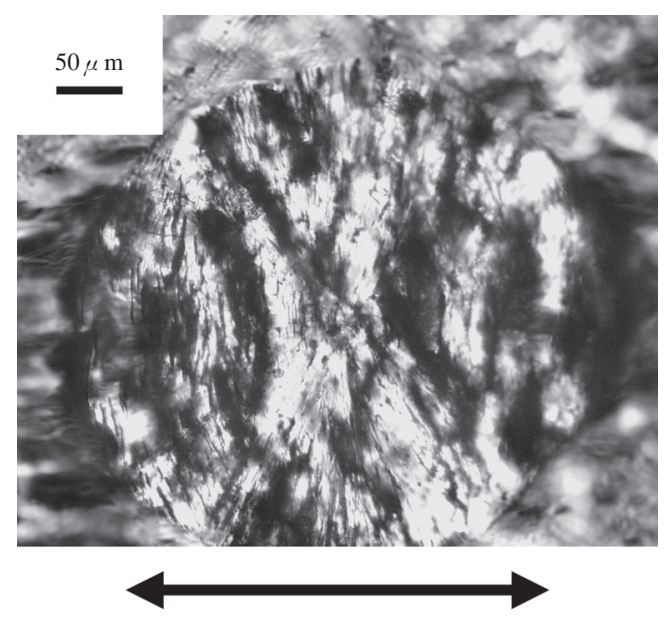

园 9 TPV-PP 60 の巨大球晶の延伸時の光学顕微鏡像. 矢印が延伸方向

\section{4. よ め}

海島構造を有する TPV のモルフォロジーと力学物性の 関係について検討した結果，以下の知見が得られた。

（1）TPV の変形初期では, 引き伸ばされた島相の赤道面 付近の iPP 海相にひずみが集中し，iPP が破砕するこ と, この結果, 架橋ゴム島相は iPP 海相による束縛か ら解放され，変形しない極地付近の iPP 相を通して, 架橋ゴム島相が変形することにより, TPV の延伸性 を発現する。

（2）海相である iPP は TPV のゴム的弾性の発現に寄与せ ず，架橋ゴム島相のみが，ゴム的弾性発現に寄与する。

（3）破砕したiPP の微細結晶が，架橋ゴム島相からの変形 を受けることにより，TPV の応力発現に寄与する.

このような結果が, オレフィン系を始め, 他の高分子系 の熱可塑性エラストマーについて, より高いゴム的弾性, 延伸性を有する新材料の開発指針を与える知見の一端とし て，活用されることを期待する。

\section{参 考 文 献}

1 ) Coran, A. Y. : Thermoplastic Elastomers, A Comprehensive Review, Legge, N. R., Holden, G. and Schroeder, H. E. editors. : Chapter 7 (1987), Hanser Publishers, Munich

2 ）伊藤雄一：高分子, 54（10）, 771（2005）

3 ) Ito, Y. : IRC 2005, 65 (2005)

4 ) Ito, Y. : SPE Automotive TPO Global Conf.2005, 53 (2005)

5 ）伊藤雄一：プラスチック工業技術研究会 第 1151 回 技術講演会，6（2005）

6 ) Ogo, Y. : Auto Plastics Asia in Bangkok 2005 (2005)

7 ) Okamoto, M., Shiomi, K., Angola, J. C. and Inoue T. : IRC 95, 71 (1995)

8 ) Okamoto, M., Shiomi, K. and Inoue T.: Polymer, 35, 4618 (1994)

9 ) Wright, K. J., and Lesser, A. J. : Rubber Chem. Tech., 74 (4), 677 (2001)

10) Wright, K. J., Indukuri, K. and Lesser, A. J. : Polym. Eng. Sci., 43 (3), 531 (2003)

11) Boyce, M.C., Kear, K., Socrate, S. and Shaw, K. : $J$. Mech. Phys. Solids, 49, 1073 (2001)

12) Boyce, M.C., Socrate, S., Kear, K., Yeh and O., Shaw, K. : J. Mech. Phys. Solids, 49, 1323 (2001)

13) Boyce, M.C., Yeh, O., Socrate, S., Kear, K. and Shaw, K. : J. Mech. Phys. Solids, 49, 1343 (2001)

14) Karacan, I., Taraiya, A. K., Bower, D. I., Ward I. M. : Polymer, 34, 2691 (1993)

15) Nitta, K., Okamoto, K. and Yamaguchi, M. : Polymer, 39, 53 (1998)

16) Huy ,T.A., Luepke, T. and Radusch, H.-J. : J. Appl. Polym. Sci., 80, 148 (2001)

17) Asami, T and Nitta, K : Polymer, 45 (15), 5301 (2004)

18) Nitta, K. and Takayanagi, M. : J. Mat. Sci., 38, 4889 (2003) 